ENTREPRENEURSHIP AND SUSTAINABILITY ISSUES

ISSN 2345-0282 (online) http://jssidoi.org/jesi/

2020 Volume 7 Number 3 (March)

http://doi.org/10.9770/jesi.2020.7.3(70)

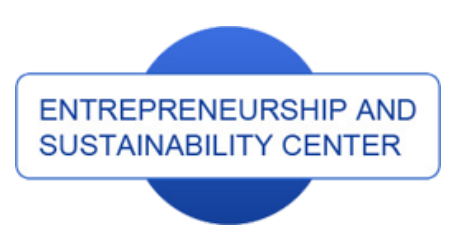

Publisher

$\underline{\text { http://jssidoi.org/esc/home }}$

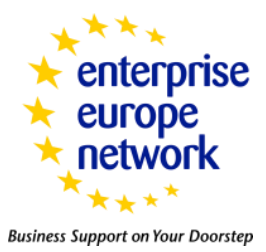

CASPA
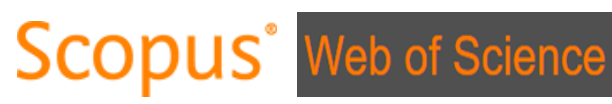

\title{
INVESTMENTS TO THE PETROCHEMICAL SECTOR: THE VALUE OF THE COMPETITIVENESS OF PETROCHEMICAL COMPANIES
}

\author{
Tatiana Bondarenko ${ }^{1}$, Alex Borodin ${ }^{2}$, Makpal Zholamanova ${ }^{3}$, Galina Panaedova ${ }^{4}$, Tatiana \\ Belyanchikova $^{5}$, Lira Gurieva ${ }^{6}$ \\ 1,2 Plekhanov Russian University of Economics, 36, Stremyanny lane, Moscow, Russian Federation \\ ${ }^{3}$ Eurasian National University named after L.N. Gumilyov, 11, Educational building No. 5, Nur-Sultan, Kazakhstan \\ ${ }^{4}$ North-Caucasus Federal University, 1, Pushkin str., Stavropol, Russian Federation \\ ${ }^{5}$ Financial University under the Government of the Russian Federation, 49, Leningradskij prospekt, Moscow, Russian \\ Federation \\ ${ }^{6}$ North Ossetian State University named after K.L. Khetagurov, 44-46, Vatutina Street, Vladikavkaz, 362025, Russian \\ Federation \\ E-mails: ${ }^{1}$ t.g.bndarenko@gmail.com, ${ }^{2} a i b-2004 @ y a n d e x . r u,{ }^{3}$ makpalzh@mail.ru, ${ }^{4}$ afina-02@ rambler.ru \\ ${ }^{5}$ maestra_@mail.ru, ${ }^{6443879 @ m a i l . r u}$
}

Received 18 June 2019; accepted 10 December 2019; published 30 March 2020

\begin{abstract}
The article focuses on the dynamics and structure of fixed investments in the Russian Federation in the period of 2011-2019, analyses both the destabilizing factors, and those, having beneficial impact on the use of a wide range of financial mechanisms in financing projects on petrochemical companies' development. It evaluates the competitiveness of petrochemical companies in the Russian Federation and abroad, for the current period and until 2030, according to the strategy of industry development. It outlines the investment potential of the industry and provides conclusion on the need to develop the use of mechanisms for financing innovative subprojects of petrochemical industry companies. All conclusions in the article are illustrated with relevant examples.
\end{abstract}

Keywords: competitiveness; financing mechanisms; financing; innovative development of the industry; investments; petrochemical companies

Reference to this paper should be made as follows: Bondarenko, T., Borodin, A., Zholamanova, M., Panaedova, G., Belyanchikova, T., Gurieva, L. 2020. Investments to the petrochemical sector: the value of the competitiveness of petrochemical companies. Entrepreneurship and Sustainability Issues, 7(3), 2510-2525. http://doi.org/10.9770/jesi.2020.7.3(70)

JEL Classifications: G31, G32 


\section{Introduction}

Russia is one of the leading oil and gas producers, however, its share of petrochemical production accounts for only $2 \%$ of the world total. Russian petrochemical production falls behind global leaders - China, the United States and Saudi Arabia by 5-8 times (Akishin, Tyrtov, 2018).

Important trends facing the petrochemical industry around the world today are the problems of the resource base and geography: deterioration in the quality of reserves, decline in reservoir productivity, and attention to lowpermeability reservoirs. The needs of the petrochemical market today is an approach when the company as a provider does not just provide a product and related services, but is ready to participate in the development of an investment solution for the task of its customer, accompany its implementation and share responsibility for the final result. It is precisely this model of development of the petrochemical market that will be further promoted as much as possible by commercializing joint developments (Grigorievna, Aleksandrovna, Vladimirovich, 2019).

\section{Litreture review}

There has been a large number of theoretical, methodological and applied research on setting development strategies for petrochemical complexes. This is due to changing trends, tools, development tendencies, and approaches to the financing of petrochemical projects in Russia and worldwide.

The issues of the management of investment projects received much attention in the works by such scientists as (Carlsson, Jacobsson, Holmen, Rickne, 2002), (Shuen, Feiler, Teece, 2014), (Luebeck, Petrov, 2018), (Borodin, Pyatanova, et.al., 2019) and others.

Fundamental works by scientists (Sterling, Murray, 2007), (Coenen, López, 2010) are also worth mentioning.

The process of investment planning in a changing environment is based on traditional foundations and uses information from open sources, and includes several stages of preparation of documentation in accordance with the main objectives of the financial planning regulation of the company, presented in Figure 1.

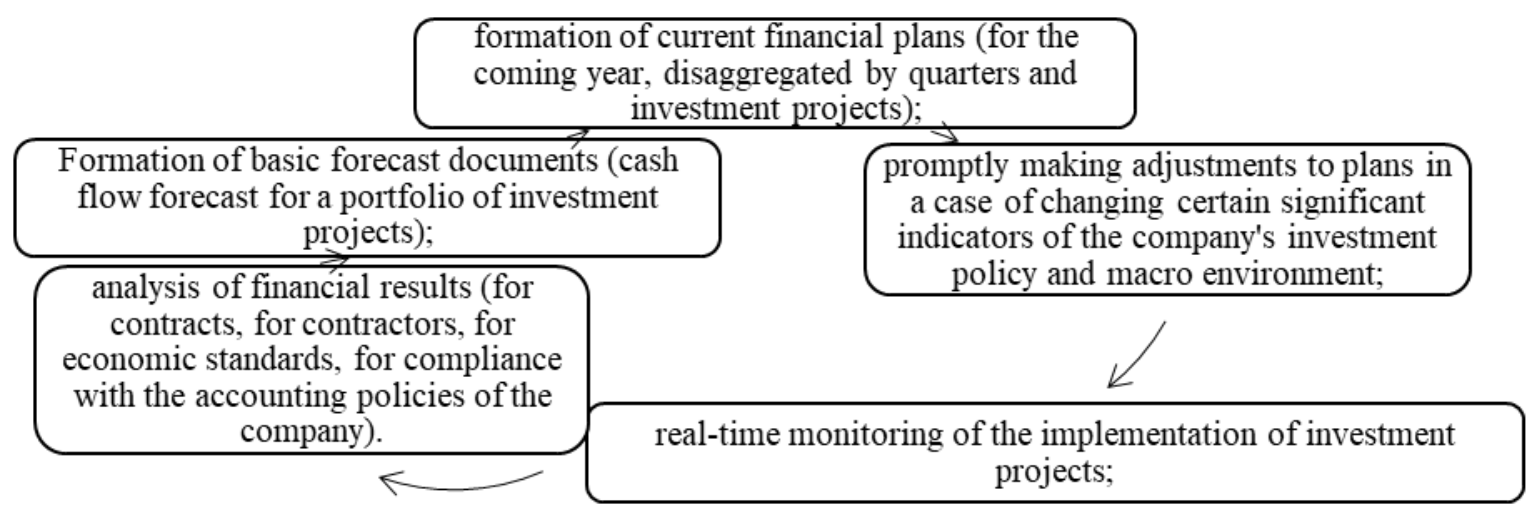

Figure 1. The process of investment planning 
ENTREPRENEURSHIP AND SUSTAINABILITY ISSUES

ISSN 2345-0282 (online) http://jssidoi.org/jesi/

2020 Volume 7 Number 3 (March)

http://doi.org/10.9770/jesi.2020.7.3(70)

The process of financial investment planning (see Figure 1) is very time-consuming, as you go through all the stages (Dudin, Lyasnikov, Sekerin, Gorokhova, Danko, Bank, 2017), (Borodin, Veynberg et.al., 2019), the planned indicators are more deeply interconnected both among themselves and with the data of the external environment. The financial plans developed on the basis of these data serve as a guide (reference point) for financing the current and investment activities of the organization.

As part of financial investment planning, financial analysis methods (Menshchikova, Sayapin, 2016) will be used to determine the implementation of financial investment plans (see Figure 2).

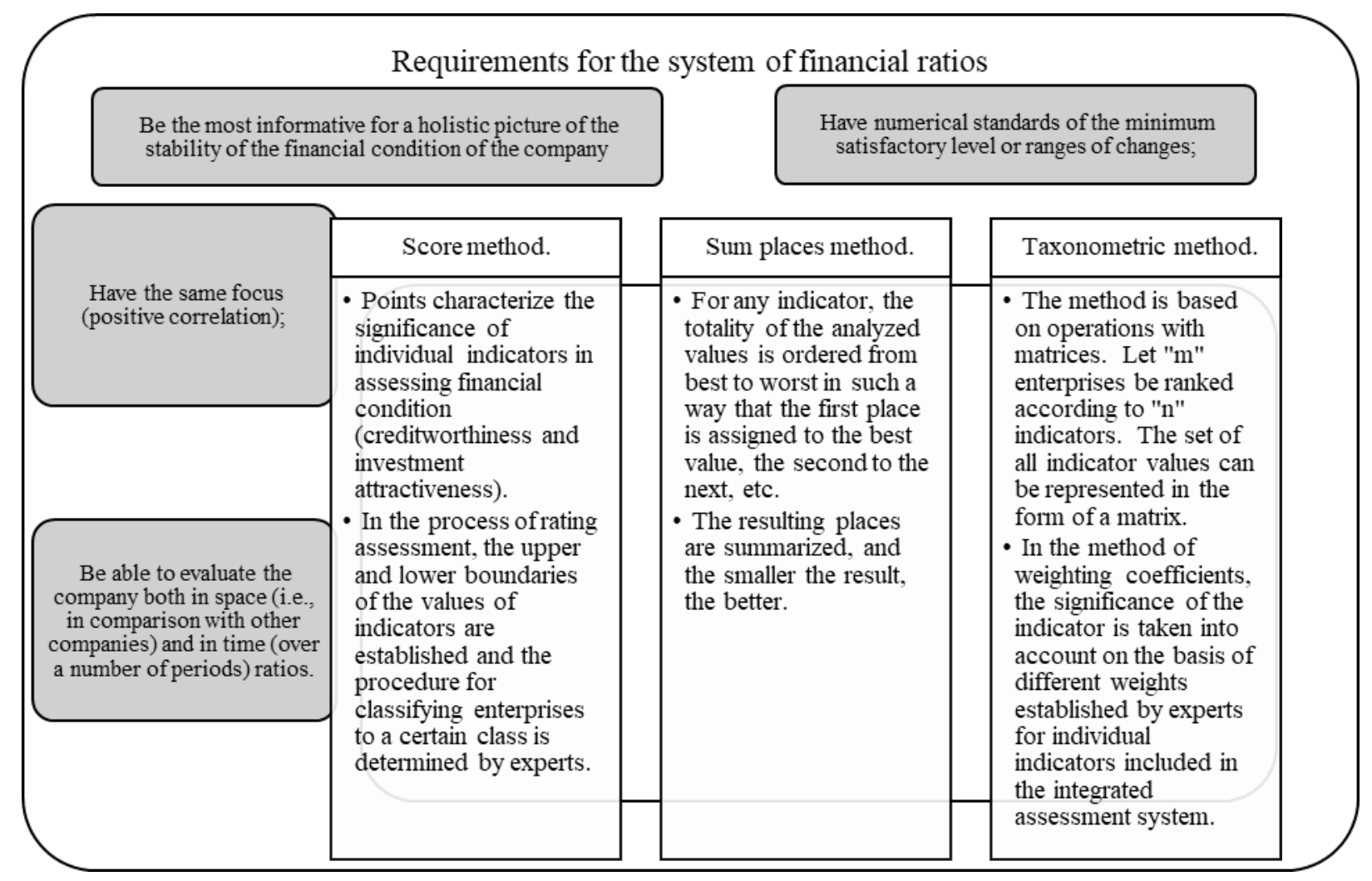

Figure 2. Financial investment analysis methods

The reality of indicators of financial investment plans largely depends on the choice of planning methods, their combination, taking into account the specifics of each (Dobrova, Danilochkina, Cherner, Dobrov, Dobrov, Sepiashvili, 2018).

It should be noted that each company develops a financial investment plan for its activities based on niche development, industry potential and its own internal individual standards, i.e. each uses its own specific methodology, allowing taking into account all the features of the business and the sphere where the activity is implemented. Of course, company managers should orient their business toward future financial competitiveness, but also take into account the need to remove unprofitable units or lines of business, identify those areas that do not correspond to the current level and require reevaluation. Justification of certain articles of financial investment plans, even in the most progressive ways, will not ensure the reality of the tasks if income and expenses are not balanced. 
ENTREPRENEURSHIP AND SUSTAINABILITY ISSUES

ISSN 2345-0282 (online) http://jssidoi.org/jesi/

2020 Volume 7 Number 3 (March)

http://doi.org/10.9770/jesi.2020.7.3(70)

The methodological framework for setting up the investment planning system is quite wide. However, at the same time, the realism and reliability of the calculated indicators of financial plans largely depends on the set of selected methods of financial planning, which is a subjective value. The reality level of the obtained forecast data depends both on the human factor in making management decisions and on the developed and installed mathematical base in an automated accounting system that allows you to combine different methods taking into account the specifics of each.

\section{Methodology}

The article discusses the dynamics and structure of investments in fixed assets in the Russian Federation in the period 2011-2018. The state of the economy of the Russian Federation predetermined its understanding as a factor condition for implementing the development strategy of the chemical and petrochemical complex in the Russian Federation for the period up to 2030. The Russian petrochemical market is characterized as a market for complex and expensive processes that are not market products, burdened with infrastructure issues and the complexity of pricing, with limited a set of sources of raw materials. The conclusions formulated are illustrated in the dynamics of the development of petrochemistry both in the industry as a whole and on the example of the development of the industry in the Siberian Federal District, where a large amount of raw materials is concentrated and the prospect of increased financial competitiveness of this business is noticeable. A description of the problems by the degree of influence on the competitiveness of the main segments of the petrochemical companies revealed the conditions for the development of the investment potential of the petrochemical industry. The authors of the article present projects for the development of petrochemical companies in the Russian Federation until 2030, characterize the investment potential of the industry, make conclusions about the need to develop the use of financing mechanisms for innovative subprojects of companies in the petrochemical industry.

Let us consider the state of Russian economy as a factor condition for this strategy implementation. Since 2011, it was characterized by reduced consumer and investment demand, slowdown in the field of investment and industrial development, lower demand for domestic production, decline in purchasing power, which altogether led to the slowdown in economic growth, in general. It is neseccary to emphasize the downward trend in the dynamics of fixed investments in the period of 2011-2015. In 2016, the negative trend was levelled out and a tendency towards recovery and increase in fixed investment growth emerged (see Figure 3). The relative stabilization of the macroenvironment in 2017 ensured the growth of real investment in fixed assets. The key drivers of growth were increasing the availability of credit as a result of lower interest rates, as well as improving the financial condition of enterprises: investments financed by own funds increased by $9.0 \%$ over the year.

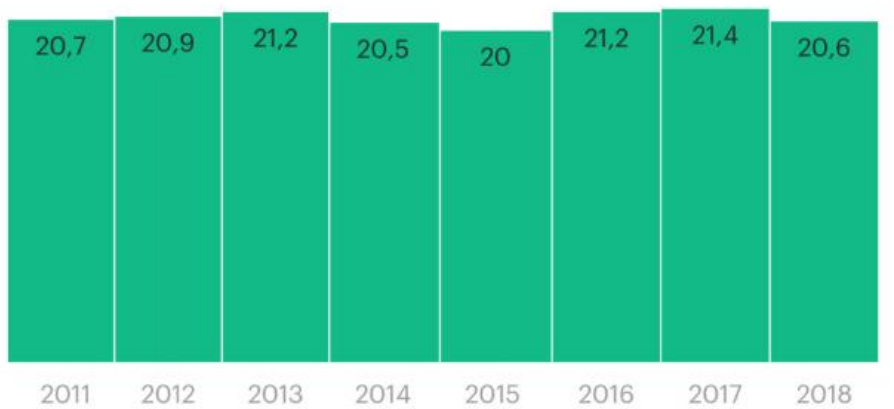

Figure 3. Dynamics of the ratio of investments in fixed assets to Russia's GDP

Source: Federal State Statistics Service http://www.gks.ru/free_doc/new_site/business/invest/tab_inv-vf.htm 
ENTREPRENEURSHIP AND SUSTAINABILITY ISSUES

ISSN 2345-0282 (online) http://jssidoi.org/jesi/

2020 Volume 7 Number 3 (March)

http://doi.org/10.9770/jesi.2020.7.3(70)

In general, we can talk about a reduction in the ratio of investment in fixed assets to Russia's GDP. At the same time, the volume of investments in fixed assets in 2018 increased in real terms by $4.3 \%$ compared to 2017 and amounted to 17.6 trillion rubles, Rosstat said earlier. And real GDP growth amounted to 2.3\%. It turns out a paradox: investments grow faster than GDP, but at the same time, the ratio of investment to GDP decreases. The contradiction (decrease) is due to the fact that the investment deflator has grown much weaker than the GDP deflator. Among the possible reasons for the restoration of investment dynamics, the stabilization of oil prices and favorable forecasts of economic growth could be indicated, as well as the observed signs of economic stabilization that positively affect changes in the index of entrepreneurial confidence.

The analysis of the data shows that despite the significant reduction in Russia's investment attractiveness both during the global crisis of 2008-2009 and poorly performing economy of 2014-2016, the general trends and structure of investment did not undergo substantial changes. In general, after the stabilization of the economic situation in 2013, the share of investments in machinery, equipment and vehicles in the structure of fixed investments reached a level of $38.8 \%$. Thereafter, there was a serious decline, and in 2015-2017, the indicator achieved a 15 - year minimum and constituted 31.5\%. Nowadays, this very segment is the targeted one for modern financial companies. However, considering the increasing competition, year by year, this segment continues growing, which forces financial companies to search and explore new markets. It can be assumed that through the implementation of a new technical strategy, Russian petrochemical companies will gain more than 130 billion rubles in financial effect by 2025 both from additional production and from an additional resource base that companies need to involve.

Thus, the main investment areas for increasing the financial competitiveness of petrochemical companies in the Russian Federation will be associated with the construction of technical centers for the development of polymer processing, where potential customers will be able to participate in the development and testing of new products and brands of raw materials.

The analysis of the data in Figure 4 shows the structure of fixed investments in 2018.

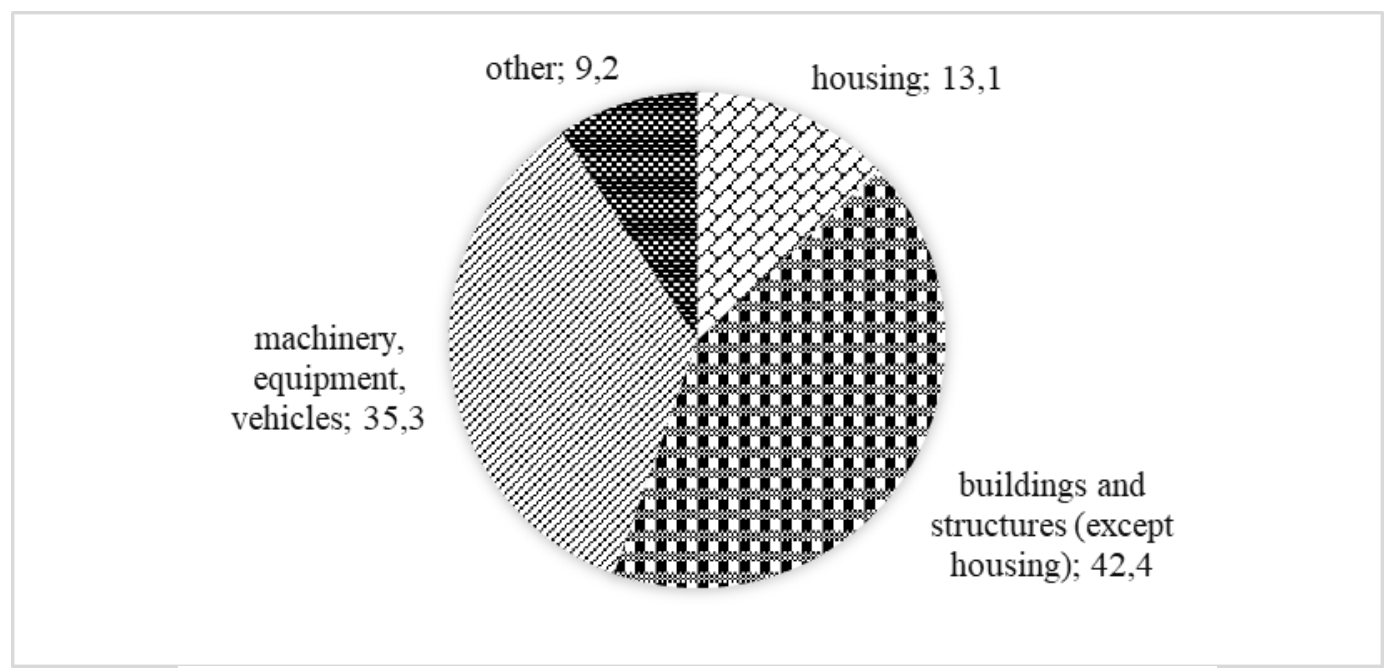

Figure 4. The structure of fixed investments in 2002-2017, by types of fixed assets Source: Federal State Statistics Service http://www.gks.ru/wps/wcm/connect/rosstat_main/rosstat/ru/statistics/enterprise/investment/nonfinancial/\# 


\section{ENTREPRENEURSHIP AND SUSTAINABILITY ISSUES}

ISSN 2345-0282 (online) http://jssidoi.org/jesi/

2020 Volume 7 Number 3 (March)

http://doi.org/10.9770/jesi.2020.7.3(70)

The deterioration of the economic situation in general, and of the investment activity in particular, can be explained by the fact that, since 2014, the negative trends in Russian economy escalated, and the currency crisis started as a result of the devaluation of the rouble against foreign currencies. The devaluation was caused by falling energy prices, as the revenues from energy resources made up a significant part of Russia's budget, as well as by the introduction of economic sanctions against Russia. Individual global companies reported on their disinvestment in the Russian Federation. The above-mentioned aspects affected the reduction of investment in general, led to withholding lending by foreign banks; the banking system introduced stricter requirements for potential borrowers, and the rates on borrowings increased, which reduced the potential capacity for innovative development of petrochemical companies in the Russian Federation through investment resources.

It is also essential to mention that the petrochemical market is the market of complex and expensive processes, which are not market goods. It is complicated by infrastructure issues and pricing complexity, and has a limited set of raw materials sources. All this allows to conclude on the weak investment and innovation position of petrochemical companies. Petrochemicals and polymer raw materials processing are far from being the strategic focus of most gas and oil refining companies, as the investments in such projects are high and EBITDA in absolute terms is incomparably lower than the revenues from operating income.

Thus, petrochemical production can most commonly be considered just a part of an integrated development project, whose economy may currently be unprofitable, mainly due to high investments in deep gas processing and petrochemistry.

The object of reseach is characterized as:

Russia today is one of the largest producers of crude oil and petroleum products: 32 large oil refineries with a total installed capacity of 310.4 million tons per year operate in Russia. Russia takes $\sim 19$ th place in the world in terms of petrochemical production (1\% of the global volume), and 11th place in terms of per capita. In Russia, for each person working in the petrochemicals, there are from $\$ 30$ thousand to $\$ 40$ thousand of the enterprise's revenue, and among world industry leaders this figure is $\$ 300$ thousand - $\$ 500$ thousand. The total volume of primary processing of crude oil in Russia increased by $2.5 \%$ (or 7 million tons) In 2018 compared to the same period in 2017 and amounted to 286.9 million tons. However, in the last four years there has been a downward trend. It should be noted that the reduction in the number of products at the same time occurred with an increase in its quality. In 2016-2018 a positive price trend took place in the markets of all petrochemical products. Ethylene and propylene prices increased by 33 and 44\%, respectively. In the aromatic segment, the maximum growth was shown by prices for benzene and styrene, increasing in 2018 compared to 2017 by 22 and $42 \%$, respectively. However, the market situation changed at the end of 2018, when oil prices, oil products prices, and polymers prices went down sharply. The situation in the Russian oil production and refining market in 2018-2019 showed a decrease in profitability, a deterioration in the economy of Russian oil refineries forced them to look for development opportunities in the petrochemical industry. The results of the first quarter of 2019 suggest a further decrease in growth rates: the chemical production index was $1.6 \%$ compared to the same period in 2018 (versus $2.2 \%$ in 2018 and $6.7 \%$ in 2017). However, by 2020, a significant improvement in production dynamics can be expected: at the end of 2019, it is expected to launch a new petrochemical complex with a capacity of 2 million tons of polymers per year.

The main competitive advantage of Russia in the field of petrochemicals is that it has a rich raw material base, because natural resources are the basic component of petrochemical production. However, while the domestic domestic market for petrochemical products is not saturated. Comparing the per capita consumption of petrochemicals in Russia abd in the developed countries, it is significantly inferior to them. Export of Russian polymers today is less than $1 \%$, while the volume of export of crude oil is $10 \%$. The share of Russia in the production of ethylene is $2.6 \%$, and in the production of plastics $-1.8 \%$. In terms of the total volume of production of chemical products, Russia ranks twentieth. 


\section{ENTREPRENEURSHIP AND SUSTAINABILITY ISSUES}

ISSN 2345-0282 (online) http://jssidoi.org/jesi/

2020 Volume 7 Number 3 (March)

http://doi.org/10.9770/jesi.2020.7.3(70)

Russia occupies quite a good position in only a few areas: in the ammonium nitrate market, the share of Russian products is $40 \%$, urea - $17 \%$, ammonia - $16 \%$.

The commodity nomenclature of exports of the chemical complex of Russia is represented mainly by products of low and medium degree of technological redistribution, which is used for further redistribution into products with high added value. The main products with export potential: mineral fertilizers - 35\%; synthetic rubber - 9\%; ammonia - 5\% (24\% of production); methanol - 2\% (53\% of production). The physical volume of export of petrochemical products in 2018 increased by $3.5 \%$ compared to 2017.

Unlike export, the nomenclature of Russian imports is diverse, traditionally goods with high added value prevail in it. A comparison of the product structure of Russian exports and imports shows that mainly low-value chemicals are exported from the country, and high-value-added products are imported: catalysts, plasticizers about $35 \%$, plastic products $23 \%$, plastics and synthetic resins $19 \%$.

At the same time, stagnating domestic consumption does not give positive signals regarding long-term development prospects. Since traditional petrochemical companies have set themselves the goal of expanding production and increasing capitalization, in order to neutralize the negative impact of the maneuver on petrochemicals, since 2022 in the Russian Federation will earn a reverse excise tax on oil with a damping component. The benefit can be given to companies investing in new production, as well as existing ones - if they invest at least 65 billion rubles in the modernization of ethane processing plants from 2021 to the end of 2026. This will allow companies to continue to regularly equalize tax conditions for different types of petrochemical feedstocks.

According to the calculations of the Ministry of Energy of the Russian Federation the reverse excise tax will attract more than 3.5 trillion rubles investments to Russia in the next 6-7 years, and increase the processing of petrochemical raw materials by $8-10$ million tons.

The fact that only operating petrochemical companies are investment-attractive should also be taken into account. In modern conditions, the chemical industry of the Siberian Federal District is experiencing increased competition from Asian and Middle Eastern producers of petrochemical products.

The contribution of the petrochemical to the region's GDP is 6-7\%. A feature of the Siberian chemical industry is its significant export orientation: in the total production, its share was $40 \%$ (while the district's share in the total volume of petrochemical production is 11.2\%). The example of calculations for the Siberian Federal District, demonstrating the negative investment-attractiveness of petrochemical activity from scratch, is presented in Figure 5. 

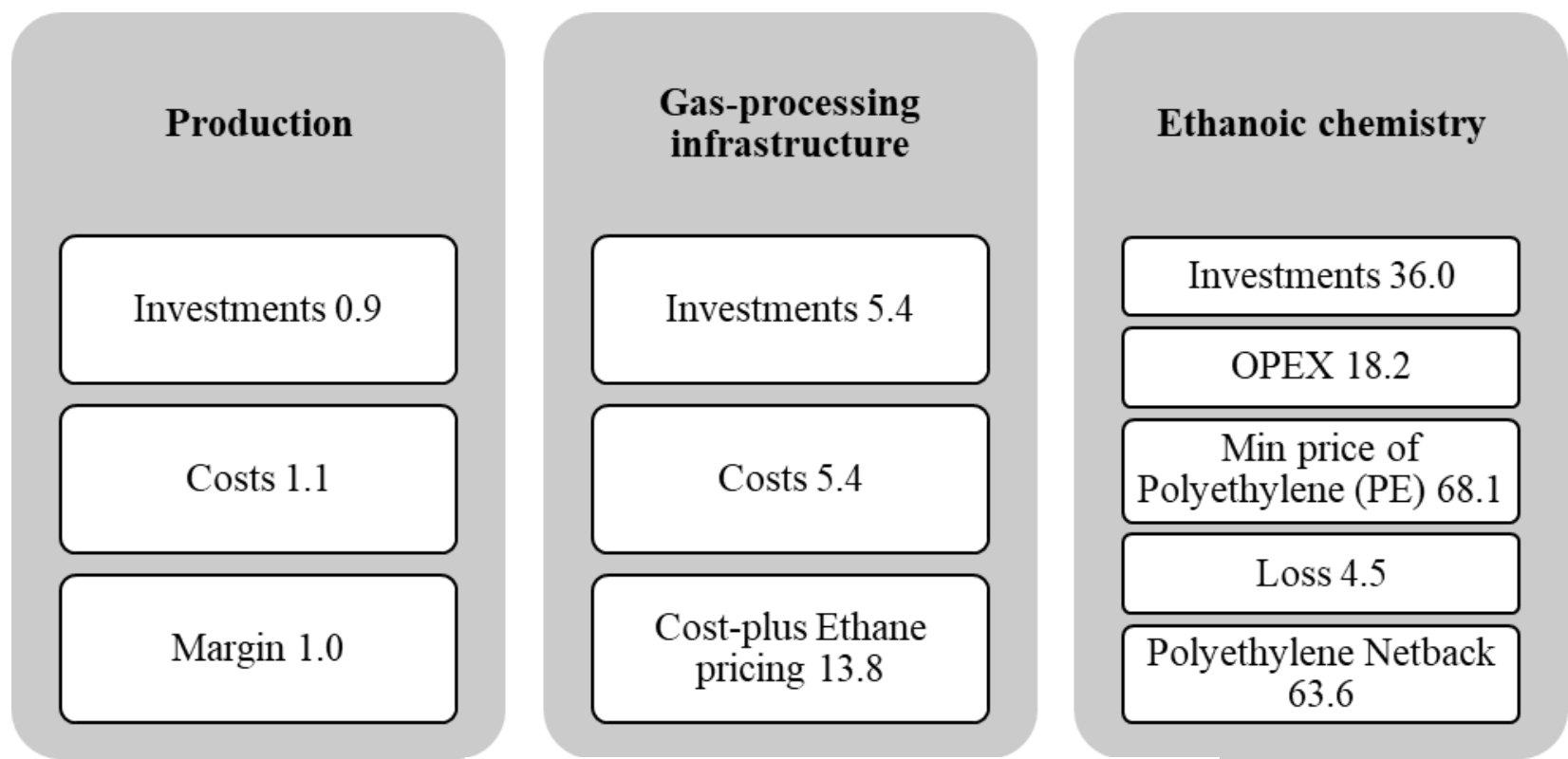

Figure 5. Economics of ethane chemistry, RUB '000 / olefins, t

The return on investment projects in the petrochemical industry of the Siberian Federal District is 6 years, while in the country this figure is about 10-12 years. This is due to the fact that petrochemical plants consist of many technological processes with high capital intensity, and a significant part of such companies is located in this part of the Russian Federation.

The existing economic situation (investments are needed in the production of semi-finished products in addition to the development of a specific production, today country's production and investment practice is based on the separation strategy of investment projects) in the country over the period analysed resulted in the need for restructuring economic policies, exploring new methods of financing and redirecting the country's economy, and for import substitution and localization of goods and services, in particular. What is more, encouraging the development of real economy became one of the important topical issues.

The sources of financing, including investments, play a major role in the implementation of any project. The modern financial mechanisms and innovative financial products hold a special position among the financial sources that companies attract in order to update the fixed assets. Moreover, they are relevant in terms of the need for the petrochemical segment organizations to adapt to the changing environment. 


\section{Results' analysis}

The factors, adversely affecting organizations' activity in the provision of mechanisms for financing investment projects in petrochemical companies are outlined in Figure 6.

Lack of transparancy in petrochemical companies' activity

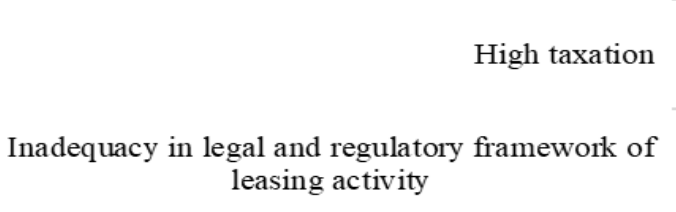

High value of money

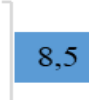

\section{8,5}

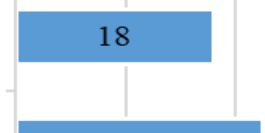

leasing activity

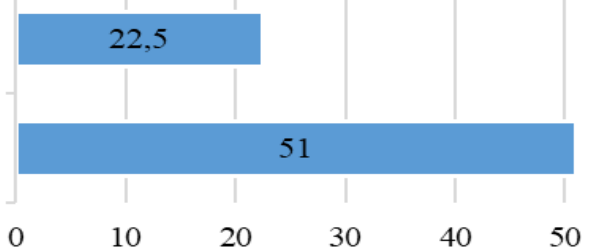

60

Figure 6. Limiting factors for the development of mechanisms for financing petrochemical projects

Nevertheless, petrochemistry serves a driver of hydrocarbons demand, and, as the international petrochemical industry shows, it is growing rapidly, due to the globally increased chemicalization of economy. Until 2030, the advanced countries of the world plan to maintain the pace of development in the petrochemical industry at a rate of $6.7 \%$ at least per annum (see table 1 ).

Table 1. Production projections for the main market segments until 2030

\begin{tabular}{|c|c|c|c|}
\hline Indicator & 2020 (planned) & 2030 (planned) & Growth indicator, \% \\
\hline \multicolumn{4}{|c|}{ Production, by the main market segments } \\
\hline Rubber, kt & 33100 & 37000 & 112 \\
\hline Synthetic rubber, kt & 19100 & 23200 & 121 \\
\hline Polystyrenes and polymers, kt & 289 & 292 & 101 \\
\hline $\begin{array}{l}\text { Processing petrochemical } \\
\text { petrochemical feedstock and } \\
\text { production of the primary products, } \\
\mathrm{kbbl} / \mathrm{d}\end{array}$ & 93,5 & 95,7 & 102 \\
\hline Synthetic fiber, kt & 65000 & 78000 & 120 \\
\hline Ammonia, kt & 179000 & 197000 & 110 \\
\hline Nitrogen, kt & 183400 & 214000 & 117 \\
\hline Carbamide, kt & 182000 & 218000 & 120 \\
\hline Phosphorus acid, kt & 56700 & 73000 & 129 \\
\hline \multicolumn{4}{|c|}{ Products consumption, by the main market segments } \\
\hline Rubber industry, kt & 31000 & 35000 & 113 \\
\hline Synthetic rubber, kt & 17700 & 22000 & 124 \\
\hline Polymers, kt & $6-10 \%$ per year & $6-10 \%$ per year & - \\
\hline Polyethylene, kt & $6-8 \%$ per year & $6-8 \%$ per year & - \\
\hline Polypropylene, kt & $3,7-6,9 \%$ per year & $3,7-6,9 \%$ per year & - \\
\hline $\begin{array}{l}\text { Processing petrochemical } \\
\text { petrochemical feedstock and } \\
\text { production of the primary products, } \\
\mathrm{kbbl} / \mathrm{d}\end{array}$ & 83,6 & 87,1 & 104 \\
\hline Synthetic fiber, kt & 62000 & 75000 & 121 \\
\hline
\end{tabular}

Source: Energeticheskij Biuleten, 2018 http://ac.gov.ru/files/publication/a/19162.pdf 
According to the Reference Technology Scenario (RTS), the demand for basic polymers in the world is projected to grow by $40 \%$ by 2030 , and by $60-65 \%$ by 2050 . The countries of the Asia-Pacific region will become the centre of the growth in production and demand for petrochemical products. The production of methanol will experience the fastest growth, which by 2030 will increase by more than $50 \%$ and will almost double by 2050, as compared with 2017. The countries of the Asia-Pacific region will account for almost two-thirds of the increase in methanol production. Ammonia production will increase by $15 \%$ by 2030 , and by $30 \%$ by 2050 , as compared with 2017. Africa and the Middle East will demonstrate the highest production growth rates: both regions will almost double the production of ammonia by 2050. The increased ammonia production will be conditioned mainly by the growing demand for nitrogen fertilizers in developing countries (Energeticheskij Biuleten, 2018 http://ac.gov.ru/files/publication/a/19162.pdf).

In this context, the following largest foreign projects are worth considering (see Figure 7):

- the project on constructing and modernizing petrochemical capacity in Azerbaijan, including the petrochemical project of SOCAR GPC valued at over \$ 4 billion;

- the plans to construct new petrochemical facilities in Atyrau Region and create a single processing chain for the production of petrochemical products with high added value (Kazakhstan);

- the project for the development of the gas and chemical industry in Turkmenistan - development strategy of "Turkmengas" State Concern.

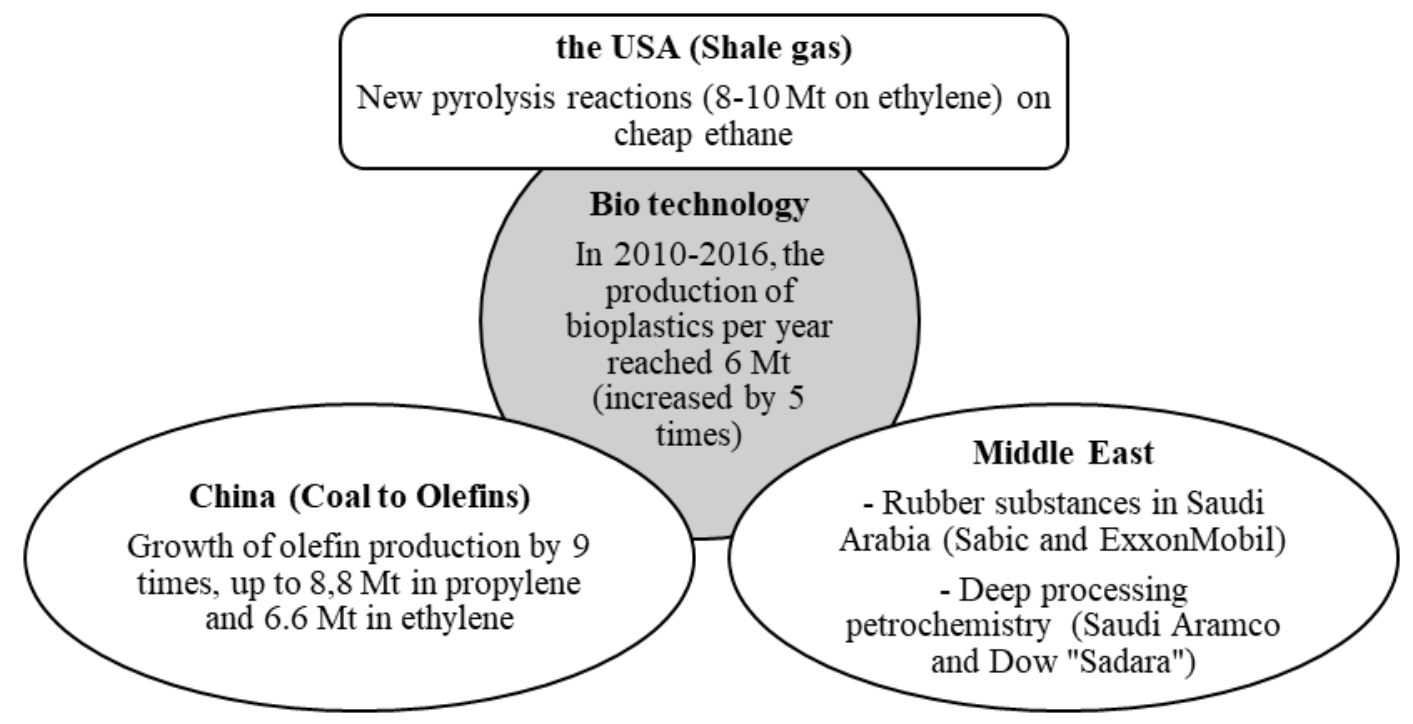

Figure 7. Competitive models of the petrochemical complexes development abroad

In recent years, the petrochemical industry in Russia has achieved some success, due to increased investment and starting up several large-scale production facilities. In 2010-2017, the production of large-capacity polymers in Russia grew by 58\% and reached 5,4 million tons. The growth was ensured by investment increase in the industry and the commissioning of new large-scale industries.

The priorities in the development of the petrochemical industry in the Russian Federation until 2030, declared at the international conference "Gas and Petrochemical Industry - 2030" are worth noting.

In terms of business objectives, the petrochemical development plan for the Russian Federation implies: 
- $\quad$ introducing modern standards for the design, construction and operation of production facilities to the whole petrochemical chain;

- programs for developing and encouraging domestic demand, industrial and domestic consumption standards and modern materials;

- $\quad$ supporting the development of industry support infrastructure, primarily in the field of energy, transport and engineering.

The implementation of the above-mentioned points should result in:

- $\quad$ a radical reduction of capital and operating costs in the industry, by $10-25 \%$ by year;

- $\quad$ the growth of domestic production and consumption (* 1,5 - 2 to GDP);

- $\quad$ import substitution in key product groups and increasing the export potential of the industry.

Among the tasks providing the implementation of the proposed priorities of the industry until 2030 are the following:

- $\quad$ staffing and educational and scientific support for the petrochemical industry to provide modern competence-based personnel structure and technological platform of the industry;

and investors;

information and analytical support for making the industry transparent for controllers, participants

- $\quad$ creating mechanisms to provide feedback from the business community, which will enable selfregulation and industry decision-making mechanisms.

Thus, prioritization of problems according to the degree of influence of the main segments of petrochemical companies on competitiveness is presented in Figure 8.

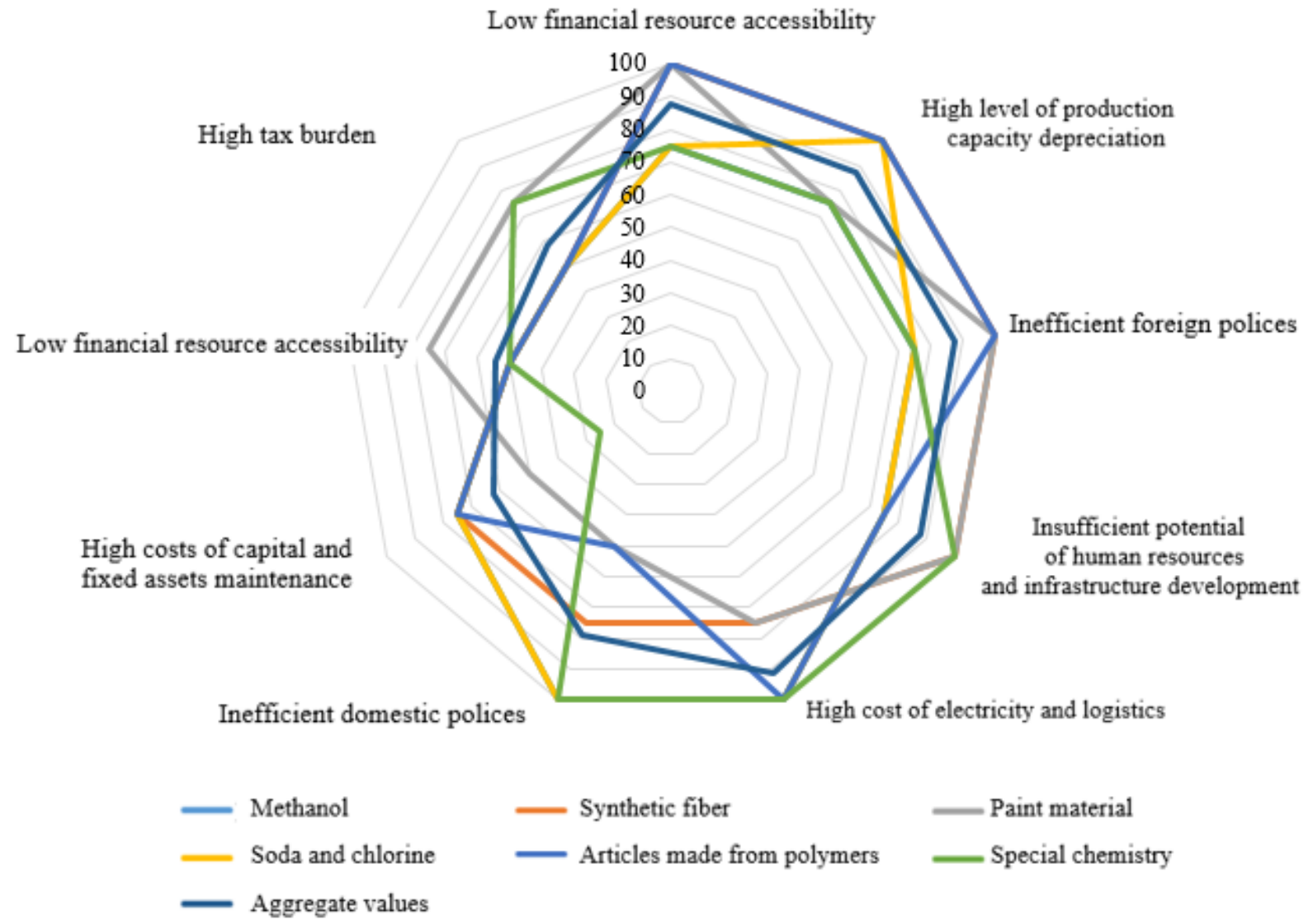

Figure 8. The degree of combined impact of individual segments of Russian petrochemical industry on the final index of competitiveness 
Therefore, from this point of view, petrochemistry should be considered one of the top priority directions of Russian economy development (see Figure 9).

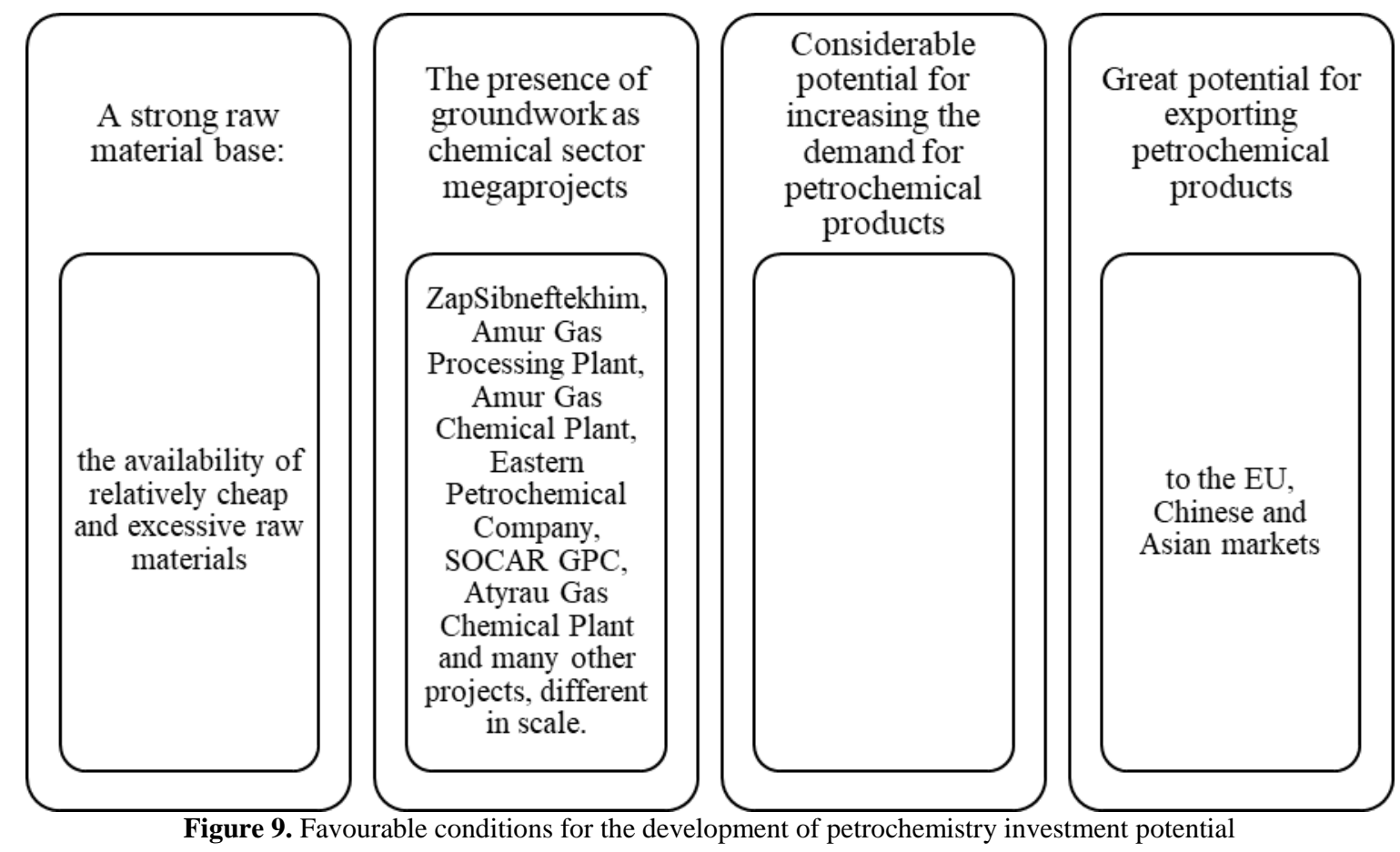

The Strategy for the development of the chemical and petrochemical complex of Russia until 2030, approved in 2016, presupposes the increased consumption of all the types of primary raw materials; naphtha and liquefied petroleum gases by 2-2,5 times, ethane - by 5 times. The growth in ethane use will primarily take place due to processing wet gas from new fields in Eastern Siberia and the Far East. By 2030, the production of large-capacity polymers will be increased up to 14,4 million tons (almost by 3 times, as compared with 2017), while their consumption will double. Thus, by 2025 , due to growing production, Russia is likely to become a major exporter of large-capacity polymers (net exports will account for 6,4 million tons), primarily, polyethylene and polypropylene. The main volume of new production will be distributed between two plants - ZapSibNeftekhim and Amursky Chemical Plant, which together will ensure the production of 3 million tons of polyethylene per year. The products are going to be exported mainly to foreign markets: the European and of the countries of the Asia-Pacific region (Energeticheskij Biuleten, 2018 http://ac.gov.ru/files/publication/a/19162.pdf). More details on the development of competitiveness in the markets and petrochemical products are available in Figure 10.

Thus, financial organizations come to realization that this potential will be developed by all means, both at the state and corporate levels. The organizational optimization resources are limited, and manufacturers are at such a stage, when the proportion of new technologies in business is growing substantially, which will proceed in future. So, today, petrochemical companies need to decide, which technologies and solutions will provide the most profitable production and output with high added value, and which financing mechanisms will be most convenient and highly-demanded. 


\section{DEVELOPMENT OF DOMESTIC DEMAND FOR PETROCHEMICAL PRODUCTS}

\begin{tabular}{|c|c|c|}
\hline $\begin{array}{c}\text { State } \\
\text { - - Programs on stimulating domestic } \\
\text { demand; } \\
\text {-- Development of new standards } \\
\text { for petrochemical products } \\
\text { consumption (automobile industry, } \\
\text { housing and public utilities) }\end{array}$ & $\begin{array}{c}\text { Industry/Business } \\
\text { •- Projects of entry / market position } \\
\text { development / sales in key growth } \\
\text { regions; } \\
\text { - - Creating new modern products / } \\
\text { solutions. }\end{array}$ & $\begin{array}{c}\text { Anticipated effect } \\
\text {-- Growth in petrochemical products } \\
\text { consumption; } \\
\text {-- New sales markets and modern } \\
\text { product structure. }\end{array}$ \\
\hline \multicolumn{3}{|c|}{ DEVELOPMENT OF EXPORT/INTERACTION WITH INTERNATIONAL ORGANIZATIONS } \\
\hline $\begin{array}{c}\text { State } \\
\text { - - Programs on protecting the } \\
\text { domestic market within the WTO; } \\
\text { - - Supporting international } \\
\text { expansion of the projects of } \\
\text { Russian petrochemical companies. }\end{array}$ & $\begin{array}{c}\text { Industry/Business } \\
\text { - - Enhancing the competitiveness of } \\
\text { the production in the Russian } \\
\text { Federation; } \\
\text {-- Certificating products to access } \\
\text { international markets. }\end{array}$ & $\begin{array}{c}\text { Anticipated effect } \\
\text {-- Development of the export } \\
\text { potential of petrochemistry of the } \\
\text { Russian Federation; } \\
\text {-- New international market } \\
\text { development. }\end{array}$ \\
\hline
\end{tabular}

Figure 10. Competitiveness in the petrochemical markets and products Source: the authors

In the paradigm of the new technological structure, there are some obvious project investments in petrochemical companies: the need to replace outdated equipment and to build new or reconstruct the existing oil pipelines.

Such changes create ample opportunities and prospects for the use of modern financing technologies (see Figure 11).

The factors positively affecting the development of mechanisms in financing investment projects of the existing petrochemical companies are:

- $\quad$ Single standard contract for each project step (project splitting)

- Incremental contractual service is well suited for the implementation of complex non-standard projects

- Low costs of work under a single standard contract

- Both non-interference and full control over the project implementation

- $\quad$ Low legal risk

- Minimum diversion of petrochemical company resources

- $\quad$ High control over the project financing. 


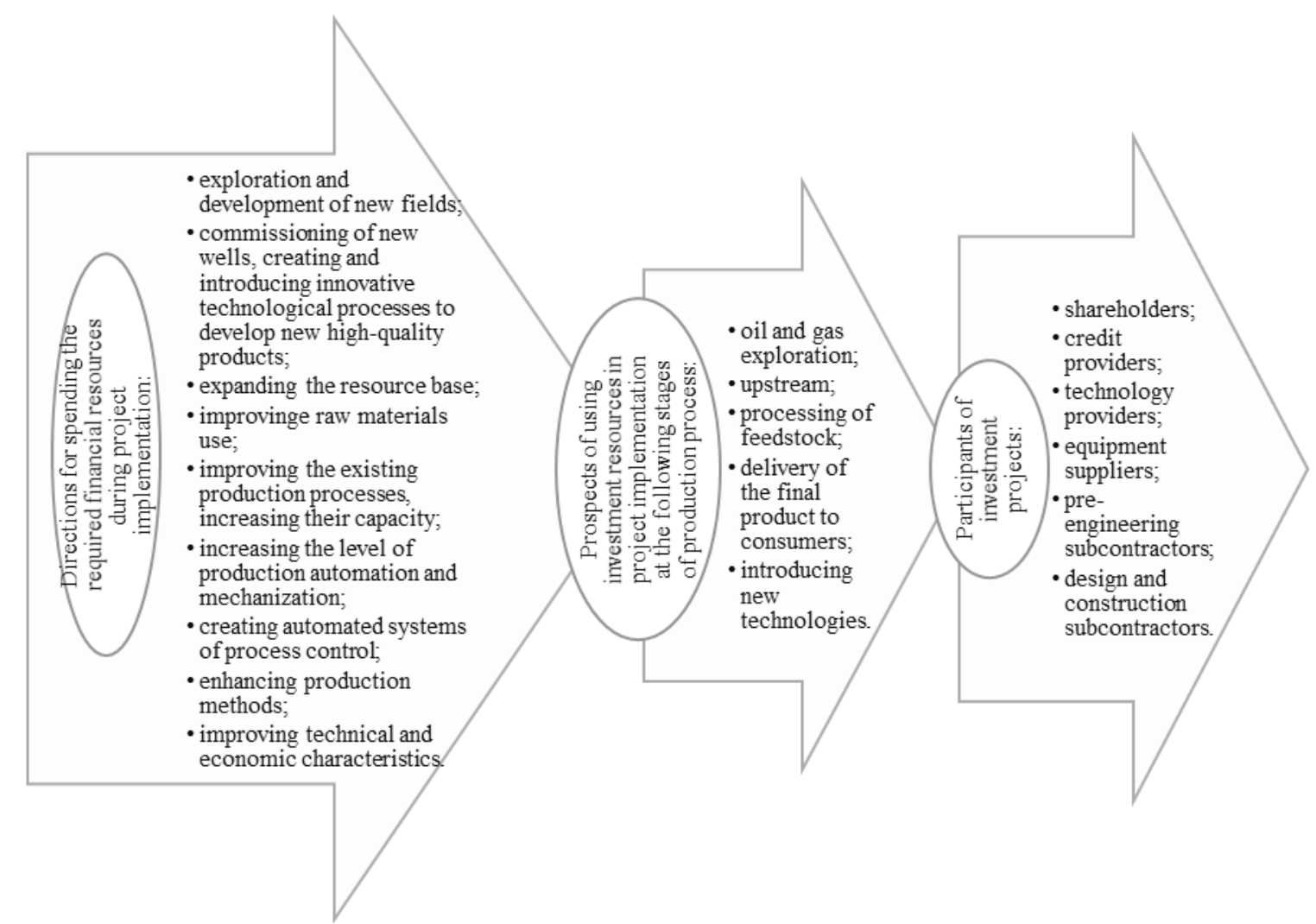

Figure 11. Standard scheme of investment project financing and implementation in the existing petrochemical companies Source: the authors

\section{Conclusions}

Naturally, petrochemical companies will constantly be trying to find ways to run more projects at lower cost, adjust to the changing conditions, introduce innovations and increase business continuity through the use of advanced technologies and solutions for improving the profitability of chemical production and economic efficiency of innovation activity.

Maximizing the profitability of investment projects and innovative projects, is possible due to optimization of raw materials in petrochemical production, according to the scenarios of changing the financial market situation.

Consequently, consistent with all the above, it can be said that modern financial mechanisms are one of the optimal tools for attracting supplementary funding for petrochemical companies. Bearing in mind the evergrowing business volumes, and complying with the recommendations for growth of the companies in the industry until 2030, the financial mechanisms offered by the market are most profitable, relevant, simple and convenient to apply to practice, not to mention other numerous advantages and state support. 


\section{ENTREPRENEURSHIP AND SUSTAINABILITY ISSUES}

ISSN 2345-0282 (online) http://jssidoi.org/jesi/

2020 Volume 7 Number 3 (March)

http://doi.org/10.9770/jesi.2020.7.3(70)

\section{References:}

Akishin, D., Tyrtov, E. Difficult petrochemistry. The industry needs support tools, which are available? Oil \& Gas Journal Russia. (2018). Available at: http://vygon.consulting/upload/iblock/1bd/difficult_petrochemistry_OGJR_12_2018.pdf

Borodin A., Pyatanova V., Yashin A. (2019). Bankruptcy Predictions for Air Carriers: Global Market. HSE Economic Journal, 23(3), 418443. https://doi.org/10.17323/1813-8691-2019-23-3-418-443

Borodin A., Veynberg R., Pisarev D., Litvishko O. (2019). Simulation of artefact detection in Viber and Telegram instant messengers in Windows operating systems. Business Informatics, 13(4), 39-48. https://doi.org/10.17323/1998-0663.2019.4.39.48

Carlsson, B., Jacobsson, S., Holmen, M., Rickne, A. (2002). Innovation systems: Analytical and methodological issues. Research Policy, 31(2), 233-245.

Coenen, L., Díaz López, F.J. (2010). Comparing systems approaches to innovation and technological change for sustainable and competitive economies: An explorative study into conceptual commonalities, differences and complementarities. Journal of Cleaner Production, 18(12), 1149-1160.

Dobrova, K.B., Danilochkina, N.G., Cherner, N.V., Dobrov, V.P., Dobrov, P.P., Sepiashvili, E.N. (2018). Innovational management of industrial enterprises in the energy sector. European Research Studies Journal, 21(1), 447-458.

Dudin, M.N., Lyasnikov, N.V., Sekerin, V.D., Gorokhova, A.E., Danko, T.P., Bank, O.A. (2017). Technological changes as the development factor of the global and Russian energy sector. International Journal of Energy Economics and Policy, 7(1), $209-215$.

Energeticheskij Biuleten. (2018) http://ac.gov.ru/files/publication/a/19162.pdf

Fixed investments in the Russian Federation by types of basic assets (at then-current prices). Official website of the Federal State Statistics Service. Available at: http://www.gks.ru/free_doc/new_site/business/invest/tab_inv-vf.htm

Grigorievna, B.T., Aleksandrovna, Z.O., Vladimirovich, D.A. Factors of inverstment efficiency and attractiveness: The case of petrochemical companies. (2019) International Journal of Recent Technology and Engineering. 8(2 Special Issue 11), $3905-3911$.

Luebeck, J., Petrov, D. (2018). Use of investment project implementation mechanism under production sharing agreement for for the development of oil and gas, European Research Studies Journal. 21(1), 650-662.

Menshchikova, V.I., Sayapin, A.V. (2016). Model of innovation-oriented state economic policy. European Research Studies Journal, 19(1), 189-200.

Petrochemistry as a driver for the hydrocarbons demand (2018). Available at: http://ac.gov.ru/files/publication/a/19162.pdf

Shuen, A., Feiler, P.F., Teece, D.J. (2014). Dynamic capabilities in the upstream oil and gas sector: Managing next generation competition. Energy Strategy Reviews, 3 (C), 5-13.

Sterling, J., Murray, C.D. (2007). Reaping value from intellectual property: DuPont's strategic approach achieves global growth. Strategy and Leadership, 35(1), 36-42.

The structure of fixed investments in 2009-2019 by types of fixed assets. Official website of the Statistics Service. Available at: http://reu.stat.university:8180/biportal/contourbi.jsp?solution=solution\&allsol=1\&project=/solution/Monitoring\&lang=en) 


\section{ENTREPRENEURSHIP AND SUSTAINABILITY ISSUES}

ISSN 2345-0282 (online) http://jssidoi.org/jesi/

2020 Volume 7 Number 3 (March)

http://doi.org/10.9770/jesi.2020.7.3(70)

Tatiana BONDARENKO is the Docent, Candidate of economic science, Associate Professor at Plekhanov Russian University of Economics.

Research interests: finance and project management; innovation and strategy; investments.

ORCHID ID: https://orcid.org/0000-0003-1009-5931

Alex BORODIN is the Professor, Doctor of economic science at Plekhanov Russian University of Economics.

Research interests: finance and regional development; innovation and digitalization; project management; sustainability

ORCHID ID: https://orcid.org/0000-0002-2872-1008

Makpal ZHOLAMANOVA Professor of the Department of Finance Eurasian National University named after L.N. Gumilyov.

Research interests: finance and regional development; innovation and digitalization; project management; sustainability

ORCHID ID: https://orcid.org/0000-0003-0942-2376

Galina PANAEDOVA is the Professor, Doctor of economic science at North-Caucasus federal university.

Research interests: regional development; innovation and marketing; project management; tourism, world economy.

ORCHID ID: https://orcid.org/0000-0001-8261-6308

Tatiana BELYANCHIKOVA, PhD, associate professor, Financial University under the Government of Russian Federation. Research interests: finance; innovation and marketing; education management; regional development.

ORCHID ID: https://orcid.org/0000-0002-3086-1683

Lira GURIEVA, is the Professor, Doctor of economic science at North-Ossetian State University named after K.L. Khetagurov, Vladikavkaz, Russian Federation.

Research interests: Economics and Finance, corporate Finance, innovation Economics, digital Economics, financial computing

ORCHID ID: https://orcid.org/0000-0002-9632-539X

Register for an ORCID ID:

https://orcid.org/register

Copyright (C) 2020 by author(s) and VsI Entrepreneurship and Sustainability Center

This work is licensed under the Creative Commons Attribution International License (CC BY).

http://creativecommons.org/licenses/by/4.0/

(c) (i) Open Access 